\title{
Changes in plant material when drying according to IR spectroscopy
}

\author{
$\underline{\text { Natalija Dmytrenko }}{ }^{1}$, Sergiy Vdovenko ${ }^{2}$ \\ 1. Institute of Engineering Thermophysics of NAS of Ukraine, Ukraine, Kiev, Bulakhovsky st. 2, \\ E-mail: natatal@ukr.net
}

2. Kukhar Institute of bioorganic chemistry and petrochemistry of NAS of Ukraine, Ukraine, Kiev, Murmanska st.1, E-mail: sergiusz@bpci.kiev.ua

\begin{abstract}
Infrared spectroscopy of parenchymal tissues of apples subjected to heat drying has shown an increase in the structural hardness of carbohydrates in the removal of water hydrated by them and a gradual violation of the structure of proteins under the influence of heat and dehydration.
\end{abstract}

Keywords - drying, infrared spectroscopy, parenchymal tissues, carbohydrates, proteins.

\section{Introduction}

Classical representations about mechanisms of dehydration of colloidal capillary-porous bodies, that sort are plant tissues, are based on the assumption that water is hold up owing to by osmosis, capillary condensation and adsorption. In doing so, the following characteristics of the material, such as porosity and the differential function of the distribution of pores from the radii, are taken into account. Very rarely, using the introduction of chemical potential, the influence of the chemical composition of the material is taken into account. But vegetable fabrics differ both in the wealth of chemical composition, and in the ability to change it under the influence of technological factors. The features of structural and chemical changes in the material can be register both in its physic-chemical and spectral characteristics. This kind of work for complex biological objects only began $[1,2]$. The purpose of our work is to study with the help of infrared spectroscopy of structural and chemical changes of plant tissues under the influence of technological factors of the drying process (heat and dehydration).

\section{Research results}

The study was carried out by infrared spectroscopy of the affected full internal reflection. For the experiments, thin $(\sim 1.5 \mathrm{~mm})$ sections of the parenchymal tissues of the "Glory to the Winner" apples were used, which were dried in an air flow of $3 \mathrm{~m} / \mathrm{s}$ at a temperature of $60{ }^{\circ} \mathrm{C}$ to obtain specimens of varying degrees of moisture. The spectra (Fig. 1) were made on an Fourier Spectrometer VERNEX 70 (Bruker), equipped with the software package OPUS TM, with standard calibration capabilities, in the $4000 \ldots 400 \mathrm{~cm}^{-1}$ frequency range in transmission format.

Based on the spectra obtained, it is possible to identify the variations of the main groups of the main components of the apple - water, sugars, fiber, hemicellulose, proteins and and. Spectra of apples of different humidity are similar in appearance. The effect of the degree of dehydration on the structure and composition of the tissues appears in detail. In the broad highfrequency absorption band with a maximum of $3310 \mathrm{~cm}^{-1}$, there may be bands of valence fluctuations $\mathrm{NH}_{\mathrm{n}}$ - and $\mathrm{OH}$-groups of all the major biocomponents, but a sharp decrease in the maximum of this band during dehydration indicates the predominance of valence fluctuations in $\mathrm{OH}$ groups of water. Intensity decrease of the high-frequency shoulder of the band in the region of $3000 \ldots 2820 \mathrm{~cm}^{-1}$, with reduction of the moisture content in the samples, the bands of valence vibrations of the $\mathrm{CH}_{\mathrm{n}}$-groups of all components are clearly manifest. This may indicate an increase in the structural stiffness of the carbohydrate blocks during drying. The bands in the region $1750 \ldots 1540 \mathrm{~cm}^{-1}$ belong to the carbonyl $\mathrm{C}=\mathrm{O}$-groups and indicate the presence of free carboxylic acids and protein components in the experimental samples. The gradual decrease of the intensity of these bands may indicate degradation and/or violation of the structure of proteins 
under the influence of temperature $\left(\mathrm{t} \geq 60{ }^{\circ} \mathrm{C}\right)$ and dehydration. There is also a gradual evaporation of carboxylic acids. In the region of $1400 \ldots 990 \mathrm{~cm}^{-1}$, oscillations of the C-O-bonds of mono-, oligo- and polysaccharides are usually manifested. Strengthening their intensity during dehydration indicates the transformation and strengthening of the structure of the carbohydrate components of the apple in the removal of hydrated water. Proportional from of the degree dewatering of the decline of the intensity of the complex band in the range $900 \ldots 400 \mathrm{~cm}^{-1}$ allows it to be identified as deformation vibrations of different on sized associate molecule water.

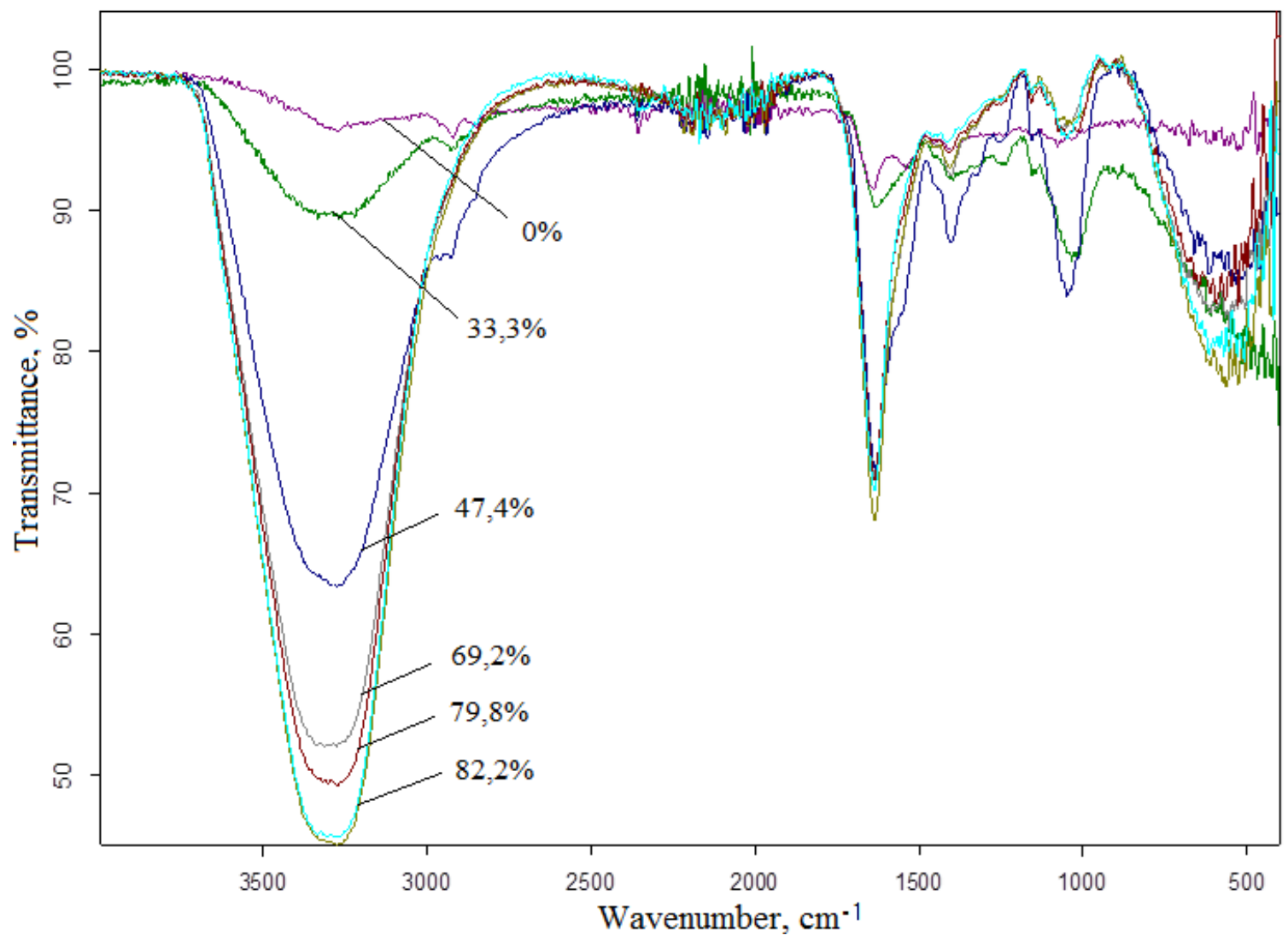

Fig.1. Infrared spectra of parenchymal tissues of apples of different degrees of humidity.

\section{Conclusion}

The conducted study allowed observing different sensitivity of carbohydrate and protein structures of the apple to the effect of heat and dehydration. The growth of structural rigidity of mono-, oligo- and polysaccharides in the removal of hydrated by them water. Gradual violation of the structure of proteins under the influence of temperature $60{ }^{\circ} \mathrm{C}$ and dehydration.

\section{References}

[1] Plotnikova L.V., Nechiporenko A.P., Orekhova S.M., Uspenskaya M.V., Plotnikov P.P., Ishevskiy A.L. Spektroskopiya otrazheniya $\mathrm{v}$ issledovanii myshechnoy tkani zhivotnogo proiskhozhdeniya. [Reflex spectroscopy in the study of muscle tissue of animal origin]. Chast I. Nauchnyy zhurnal NIU ITMO. Seriya «Protsessy $i$ apparaty pishchevykh proizvodstv», no. 2, pp. 29-39, 2017.

[2] Filippov V.I., Nechiporenko U.Yu., Kudinov R.Ye., Kudinova S.Yu. Vliyanie sposoba sushki na spektralnye kharakteristiki kornya kornevoy petrushki [The influence of the method of drying on the spectral characteristics of the root of the root parsley]. Nauchnyy zhurnal NIU ITMO. Seriya «Protsessy i apparaty pishchevykh proizvodstv», no. 2, pp. 4454, 2018. 